\title{
Heterotopias Fotojornalísticas
}

\section{Júlia Capovilla Luz Ramos}

Universidade do Vale do Rio dos Sinos jcapovilla8@hotmail.com

\section{Beatriz Marocco}

Universidade do Vale do Rio dos Sinos bmarocco@unisinos.br

\section{Resumo}

O presente trabalho se debruça sobre o conceito de heterotopia (FOUCAULT, 1987; 1998; 2005), para entender os blogs de fotografia dos jornais de maior circulação no Brasil como espaços que se diferenciam dos periódicos impressos não somente em função do suporte de publicação das fotografias, mas principalmente por engendrarem dinâmicas produtivas distintas, apesar das dependências complexas que operam e deixam transparecer quando investigamos este material mais de perto. A produção imagética presente nos blogs mostra 0 esforço por parte dos fotojornalistas em criar um espaço outro para publicação das fotografias sem, contudo, deixarem de refletir sobre a natureza da operação que executam, as limitações contidas na própria ferramenta blog e a vontade de incluir mais liberdade e poesia em tais produções.

Palavras-chave: Blog de fotografia, Heterotopia, Foucault, Fotojornalismo.

\begin{abstract}
This paper presents a study on heterotopia (FOUCAULT, 1987; 1998; 2005), as so to understand the photography blogs at the largest Brazilian newspapers websites as spaces that differentiate themselves from the print editions, not only because of their support to publish the photos, but mainly for their different production dynamics, notwithstanding the complex dependencies that operate and let them be shown when we investigate these objects closer. The image production present at the blogs shows the effort made by photojournalists to create another space to publish their photos, without, however, bearing their thoughts on the nature of the operation being executed, the limitations that the blogging tools have and the willing to include more freedom and poetry at these productions.
\end{abstract}

Keywords: Photography blog, Heterotopia, Foucault, Photojournalism. 
Sob o reinado de Chronos, os jornalistas não cansam de bradar contra as pressões e amarras que configuram as práticas e os produtos comunicacionais na atualidade, cuja velocidade de publicação parece ser mais relevante que a própria informação. Que a acusação se fundamenta, ninguém duvida. Porém, em nome da pulsação ininterrupta de nossos dias, capaz de transfigurar até as atividades mais banais, a temporalidade tem recebido especial atenção do campo. Tal movimento, embora altamente justificável, acabou por ofuscar seu parceiro mais fiel: o espaço, relegado ao papel de coadjuvante nos estudos em Jornalismo. Neste sentido, pesquisas realizadas por filósofos, historiadores, sociólogos e artistas abrem excelente caminho para pensar de forma complexa os inúmeros espaços jornalísticos emergentes a partir do advento da Web. Transpor o conhecimento talhado por outras disciplinas afim de problematizá-los sob o ponto de vista comunicacional é tentar trazer o espaço para o centro dos debates da área; o que nos parece tarefa bastante desafiadora e urgente.

É objetivo deste artigo, portanto, pensar os blogs de fotografia dos jornais de maior circulação do Brasil como espaços que se diferenciam dos diários impressos aos quais estão ligados não somente por serem suportes diferentes para a publicação do material fotográfico, mas principalmente por engendrarem dinâmicas profissionais e estéticas marcadamente distintas, mesmo que, concomitantemente, muitas das fotografias publicadas nesses espaços sejam oriundas da cobertura realizada para tais jornais. Inicialmente, duas hipóteses se apresentam: os blogs de fotografia são espaços criados apenas para escoar a produção fotojornalística não utilizada pelos impressos ou, pelo contrário, justamente por apresentarem maior amplitude temporal e espacial com relação ao papel, os blogs de fotografia são espaços considerados qualitativamente ideais para a criação e publicação do material imagético elaborado pelos fotojornalistas?

Assim, partiremos dos conceitos de heterotopia (FOUCAULT, 1987; 1998; 2005) e nãolugar (AUGÉ, 1994) para finalmente refletir sobre os blogs de fotografia como espaços outros de criação e circulação da produção fotojornalística, cuja característica mais significativa parece ser a vontade de incluir mais liberdade e poesia nas produções, sem deixar de refletir sobre a natureza dessa operação e o ciclo de vida desses blogs. Antes disso, porém, acreditamos ser necessária a revisão do conceito de espaço, funcionando como elemento articulador das reflexões que pretendemos levar à cabo.

\section{Ideias ao redor do espaço}

Afinal o que é espaço? Para Castells (1999, p. 435-436), o espaço físico "não pode ser definido fora da dinâmica da matéria", assim como o espaço social "não pode ser definido sem referência às práticas". Isto quer dizer que, do ponto de vista da teoria social, o espaço se define pelas atividades que nele transcorrem em certos períodos. Ou seja, o espaço "é o suporte material de práticas sociais de tempo compartilhado" (CASTELLS, 1999, p. 436). 
Igualmente, Michel de Certeau (2012, p. 184) j3 já definia o espaço como "um lugar praticado", palco das ações realizadas por sujeitos históricos. No entanto, o autor propunha uma diferenciação entre "lugar" e "espaço", mesmo que ambos necessitassem ser localizados no tempo. O lugar seria um ponto físico definido por coordenadas; já o espaço, ganha vida somente quando posto em movimento. Estas duas perspectivas teóricas, no entanto, partem do princípio de que todo o espaço é concreto, embora sua concretude só possa ser atingida através do desenvolvimento sistemático das atividades nele empreendidas.

Não por acaso que, para Giddens (2003, p. 25), a rotina, ou "tudo o que é feito habitualmente" é elementar à atividade social. A natureza repetitiva dos feitos realizados dia após dia, traduzida no termo "cotidiano", seria a grande responsável pela produção simbólica dos espaços. Isso não quer dizer, contudo, que o espaço seja somente a tradução do que nele se instala ou a forma que adquire. Ele se caracteriza, sobretudo, pela rede de relações que opera.

Entretanto, Michel Foucault se refere às práticas não somente como modos regulares e recorrentes de se fazer algo, mas também como "la relación entre los medios utilizados y los fines que se persiguen" (apud CASTRO, 2014, p. 139-140). Em Foucault (1987), o espaço é, portanto, não só lugar de atuação dos poderes reguladores, mas sobretudo da aparição de saberes transgressores e de resistência. O pensamento, em certo sentido, encontra similitudes na concepção proposta pelo filósofo Henri Lefebvre (2006) na obra A produção do espaço, para quem o espaço não existe a priori nem "em si mesmo", sendo necessário produzi-lo a partir dos jogos de força e das tensões geradas pelos diferentes atores sociais.

Em nossa sociedade "líquido-moderna", descrita por Bauman (2007), todavia, pouco importa a consistência dos espaços, o primordial é a dinâmica que empreendem; que eles se renovem, tornem possíveis outros modos de fazer, que sejam mutáveis e mutantes; perecíveis. O espaço, portanto, seria uma abstração que só passa a ter significado quando reinventado constantemente.

\section{Espaços outros}

Marc Augé (1994) vai trabalhar o conceito de lugar de forma distinta de Michel de Certeau (2012), por exemplo, ao rejeitar uma oposição entre lugar e espaço e propor uma diferenciação entre lugar e não-lugar. Em Augé (1994), os lugares são essencialmente antropológicos, pois deixam transparecer relações simbólicas e construções identitárias. Em oposição aos lugares antropológicos, os não-lugares seriam espaços fugidios, praticado pelos indivíduos solitários, incapazes de estabelecer relações estáveis e frutos da supermodernidade. Embora antagônicos, lugar e não-lugar padecem do mesmo mal, segundo o autor: "o primeiro nunca é completamente apagado e o segundo nunca se realiza totalmente" (AUGÉ, 1994, p. 74). Tal instabilidade facilita a aproximação do conceito de não-lugar ao conceito de

33 A primeira edição do livro "A invenção do Cotidiano", de Michel de Certeau, data de 1980. 
heterotopia trabalhado por Foucault $(1987 ; 1998 ; 2005)^{34}$. A similitude entre eles foi assinalada pelo próprio Augé (1994, p. 102) quando diz que: "o não-lugar é o contrário da utopia". Para Foucault, as heterotopias estão, sem dúvida, em oposição às utopias. A pesquisadora Maria Luna (in CATALÁ, 2014, p. 207), ao utilizar o conceito foucaultiano para pensar o cinema documental, afirma que: "la heterotopia o espacio-otro, según Foucault, se define en oposición a la utopía porque es un lugar que efectivamente existe, pero por fuera del sistema regular".

As perspectivas de Augé (1994) e Foucault $(1987 ; 1998 ; 2005)$ se diferenciam na medida em que avançamos no entendimento sobre elas. Conforme Augé (1994), os nãolugares se caracterizam pela incapacidade de colocar em prática qualquer modelo-padrão de comportamento ou prática social. Já as heterotopias, para Foucault (1998), funcionariam como "contra-sítios" capazes de tornar possíveis os encontros e promover ações concretas, ou seja,

espécies de utopias realizadas nas quais todos os outros sítios reais dessa dada cultura podem ser encontrados, e nas quais são, simultaneamente, representados, contestados e invertidos. Este tipo de lugar está fora de todos os lugares, apesar de se poder obviamente apontar a sua posição geográfica na realidade. Devido a estes lugares serem totalmente diferentes de quaisquer outros que eles refletem $\mathrm{e}$ discutem, chamá-los-ei, por contraste às utopias, de heterotopias (FOUCAULT, 1998)

No que tange ao entendimento do tópico foucaultiano é preciso, portanto, entender que ele não rompe radicalmente com os espaços concretos, mesmo desejando subverter a ordem estabelecida; ele dá a ver versões idealizadas desses espaços num mundo virtual que inquieta e desafia. Conforme o professor da Universidade Autónoma de Barcelona, Josep M. Catalá Doménech (2012, p. 60), mais do que se opor às utopias, as heterotopias aparecem como alternativas às utopias, "en el sentido que le confieren un espacio real a ese espacio imaginario".

Outra característica marcadamente distinta entre os conceitos de Foucault (1987; 1998; 2005) e Augé (1994) é que, para o primeiro, qualquer época ou cultura é capaz de produzir espaços outros de contra-poder; já para o segundo, tais espaços só podem ser pensados dentro do contexto da supermodernidade, o que implica práticas extremamente individualistas. Neste sentido, "si la heterotopia apunta a la resistencia y la colectividad, el no lugar apunta a la soledad y el anonimato" (LUNA in CATALÁ, 2014, p. 212). A perspectiva que se adota aqui,

34 O termo foi utilizado por Foucault inicialmente no prefácio do livro Le Mots et les Choses, cuja primeira edição francesa data de 1966. Foi, contudo, retomado e apresentado pelo autor em 14 de março de 1967 durante uma conferência no Centre d'Études Architecturales de Paris, que resultou no artigo Des Espaces Autres, publicado somente anos depois em Architecture, Movement, Continuité, 5, de 1984. Em português, existem somente duas traduções do artigo: uma em versão digital publicada no site virose.pt em 1998 e revisitada em 11 de fevereiro de 2005, e outra presente na Revista de Comunicação e Linguagem da Universidade Nova de Lisboa de junho de 2005. Para este artigo, além das duas versões acima, estamos utilizando também a $4^{\circ}$ edição brasileira do livro "As Palavras e as Coisas" publicada pela editora Martins Fontes em 1987. Ainda, é relevante apontar que, segundo Johnson (2012, p.1), "heterotopia is originally a medical term referring to a particular tissue that develops at another place than is usual. The tissue is not diseased or particularly dangerous but merely placed elsewhere, a dislocation". 
portanto, é a de que heterotopias e não-lugares, embora sendo conceitos que se entrecruzam, possuem, cada qual, especificidades que não devem ser negligenciadas.

Etimologicamente, a palavra de origem grega significa outro (heteros) lugar (topos + ia), que, a partir da modernidade, passou a designar o local onde se acumulavam objetos ou pessoas que se julgava desviante em relação às normas estabelecidas, ou, ainda, de coisas que não teriam sido previamente planejadas nem poderiam ser usualmente encontradas nestes espaços, como os hospícios (que seriam os locais destinados aos "loucos"), as prisões (local dos "delinquentes") ou os museus (local dos "objetos antigos"). Por isso que o conceito foucaultiano chamou tanto a atenção de áreas do conhecimento exógenas ao campo comunicacional, como, por exemplo, os trabalhos empreendidos pelos geógrafos Relph (1991), Soja (1993, 1995), Harvey (2000), que utilizaram a ideia para problematizar os limites da geografia moderna.

Devido a amplitude do conceito, uma vez que Foucault $(1987 ; 1998 ; 2005)$ não o trabalhou à exaustão, deixando margem para desdobramentos teóricos futuros, parece-nos pertinente apontar os seis princípios que regem as heterotopias descritos originalmente pelo autor francês e resumidas por Luna (in CATALÁ, 2014, p. 207-208):

1. São universais, no sentido em que aparecem em todas as culturas, ainda que possam ser classificadas entre heterotopias de crise e de desvio.

2. Possuem diferentes funções em cada sociedade, de acordo com a cultura na qual se manifesta.

3. São capazes de justapor num só espaço vários outros que seriam incompatíveis entre si.

4. Reúnem diferentes camadas temporais ou heterocronias que implicam rupturas com o sentido tradicional de tempo.

5. Pressupõem um sistema de abertura e fechamento que permite acessá-las ao mesmo tempo que também as torna impenetráveis.

6. Mantêm relações com todos espaços à sua volta; ora criando alternativas, ora contrastando com eles.

Os tópicos acima descritos, funcionam aqui como elementos articuladores para se pensar os blogs de fotografia como heterotopias jornalísticas, proposta que desenvolveremos a seguir.

\section{Heterotopias jornalísticas}

Historicamente, a entrada dos jornais no mundo virtual se deu em diferentes momentos e de forma gradual, desde a simples reprodução do material impresso em meados dos anos 1990 até a criação de produtos específicos para a web já no século XXI. Palacios (et. al, 2002) identifica três fases ${ }^{35}$ distintas do chamado "webjornalismo":

35 Oliveira (2015) descreve mais duas fases do jornalismo digital baseado nos textos de Barbosa, Palácios e Machado. 
$\leftarrow$ fase da "transposição": reprodução de grande parte do material disponível na versão impressa;

$\leftarrow \quad$ fase da "metáfora": ainda que parte da versão impressa continuasse a ser reproduzida, as potencialidades da web começam a ser exploradas e experimentadas;

$\leftarrow \quad$ fase do "webjornalismo" (propriamente dito): os jornais passam a ser encarados como produtos específicos da web, com características e potencialidades próprias, consolidando-se como sites ou portais de notícia e tornando-se mais independentes do modelo impresso.

No bojo desses acontecimentos, a entrada dos jornais de maior circulação do Brasil na Internet se deu entre meados da década de 1990 e início do ano 2000 (Tabela 1).

TABELA 1

Ano de entrada na internet dos jornais impressos de maior circulação diária do Brasil

\begin{tabular}{|l|l|}
\hline $\begin{array}{l}\text { JORNAIS } \\
\text { BR }\end{array}$ & $\begin{array}{l}\text { ANO ENTRADA } \\
\text { INTERNET* }\end{array}$ \\
\hline $\begin{array}{l}\text { Super } \\
\text { Notícia }\end{array}$ & 2010 \\
\hline Folha de SP & 1996 \\
\hline O Globo & $\begin{array}{l}1996 / 2000 \text { (dentro do } \\
\text { portal G1) }\end{array}$ \\
\hline Estadão & $\begin{array}{l}1996 / 2000 \text { (fusão dos sites } \\
\text { Ag. Estado, O Estado de SP } \\
\text { e Jornal da Tarde } \\
\text { resultando no portal } \\
\text { Estadao.com) }\end{array}$ \\
\hline \begin{tabular}{l}
2000 (dentro do portal G1) \\
\hline Extra
\end{tabular} & $\begin{array}{l}1995 / 2000 \text { (dentro do } \\
\text { clicRBS) }\end{array}$ \\
\hline Zero Hora & - \\
\hline Daqui & 2000 \\
\hline $\begin{array}{l}\text { Diário } \\
\text { Gaúcho }\end{array}$ & $\begin{array}{l}2009 \text { (dentro do portal } \\
\text { r7.com) }\end{array}$ \\
\hline $\begin{array}{l}\text { Correio do } \\
\text { Povo }\end{array}$ & - \\
\hline Aqui & \\
\hline
\end{tabular}

*Dados extraídos do copyright dos sites dos jornais ou do histórico dos mesmos. FONTE - Elaborado pelas autoras

A busca pela aceleração da expansão no ambiente virtual, portanto, fez com que veículos tradicionais de notícias recorressem, dentre outras estratégias, ao amplo uso de

Seriam elas: a quarta geração "que se baseia no paradigma do banco de dados e compreende o jornalismo colaborativo, além de possibilidades de customização do conteúdo"; e a quinta fase "caracterizada pelo uso de mídias móveis como tablets e celulares, com conteúdo desenvolvido para (e disponibilizado através de) aplicativos específicos para esses dispositivos, marcada por um nível expressivo de replicação de conteúdos em multiplataformas" (OLIVEIRA, 2015, p. 58). 
plataformas de distribuição de conteúdo. Neste contexto de plena adesão digital, de estratégias de convergência e reconfiguração das redações, passam a ser criados blogs. Tais plataformas inauguram o que muitos autores chamaram de blogs jornalísticos (ESCOBAR, 2009; FOLETTO, 2009a, 2009b; ADGHIRNI \& PEREIRA, 2006), ou seja, plataformas que se ligam de alguma forma às empresas jornalísticas e/ou a nomes consagrados na área por publicarem basicamente material advindo das apurações. Além disso, Escobar (2009) salienta que uma das principais características deste tipo de blog é tornar seus endereços eletrônicos amplamente conhecidos para atrair maior audiência.

Foletto (2009b, p. 32-54) fornece dados importantes sobre o surgimento dos weblogs e sua incorporação pelas empresas jornalísticas: originários da década de 1990, somente receberam o nome weblog em 1997 e, dois anos depois, já eram populares em função das plataformas gratuitas como o blogger. Em 1998 ganharam status jornalísticos com a publicação do caso extraconjugal de Bill Clinton com a estagiária Monica Lewinsky ${ }^{36}$, mas só passaram a ser utilizados pela imprensa brasileira a partir de 2003 com "a criação do Diário de Bagdá pelos repórteres Sérgio Dávila e Juca Varella, da Folha de S. Paulo". Contudo, o autor enfatiza que a efetiva aproximação dos blogs com o jornalismo,

tem como marco inicial o ano de 2001. Embora ela já se rascunhasse alguns anos antes, com a criação dos primeiros blogs em meados da década de 1990, é em 2001, principalmente com os atentados terroristas às Torres Gêmeas do World Trade Center em 11 de setembro, que os weblogs passam a ter visibilidade para o grande público e, como consequência disso, passa a ser vislumbrada a função que eles poderiam ocupar no jornalismo (FOLETTO, 2009a, p. 199).

O boom dos blogs jornalísticos se deu a partir de 2003 nos Estados Unidos, sendo que três anos depois, 86\% dos 100 maiores jornais americanos já faziam uso da ferramenta em seus sites e portais (PALACIOS; MUNHOZ, 2007, p. 78). No Brasil, a incorporação dos blogs pela imprensa se dá de forma exponencial entre 2003 e 2006. O que chama a atenção, todavia, é que os blogs de fotografias disponibilizados nos sites destes jornais brasileiros datam, em sua maioria, de 2009, portanto, quase uma década após a chegada dos periódicos brasileiros na rede, conforme Tabela 2.

36 Ramonet (1999, p. 56) não considera "jornalística" a revelação do caso Clinton-Lewinsky. Para o autor, o americano que revelou o caso, Matt Drudge, é "somente um homem da multimídia". Sobre a relação jornalismo e internet, Ramonet (1999, p. 56) é categórico: "as novas tecnologias favorecem o desaparecimento da especificidade do jornalismo. (...) Assim, a Internet permite a qualquer pessoa não só ser efetivamente, à sua maneira, jornalista, mas até encontrar-se à frente de uma mídia de alcance planetário". 
TABELA 2

Jornais de maior circulação no Brasil e ano de criação de seus respectivos blogs de fotografia

\begin{tabular}{|l|l|l|}
\hline $\begin{array}{l}\text { JORNAIS } \\
\text { BR }\end{array}$ & ANO ENTRADA INTERNET & $\begin{array}{l}\text { ANO CRIAÇÃO BLOGS DE } \\
\text { FOTOGRAFIA* }\end{array}$ \\
\hline $\begin{array}{l}\text { Super } \\
\text { Notícia }\end{array}$ & 2010 & - \\
\hline Folha de SP & 1996 & - \\
\hline O Globo & $\begin{array}{l}1996 / 2000 \text { (dentro do portal } \\
\text { G1) }\end{array}$ & $\begin{array}{l}2008 \text { - FotoGlobo (encerrou em } \\
2013)\end{array}$ \\
\hline $\begin{array}{l}\text { Estadão } \\
\text { Estado, O Estado de SP e Jornal } \\
\text { da Tarde resultando no portal } \\
\text { Estadao.com) }\end{array}$ & $\begin{array}{l}2009 \text { - Olhar sobre o mundo } \\
\text { desatualizado desde 2014) }\end{array}$ \\
\hline Extra & 2000 (dentro do portal G1) & - \\
\hline Zero Hora & $1995 / 2000$ (dentro do clicRBS) & 2009 - FocoBlog \\
\hline Daqui & - & - \\
\hline $\begin{array}{l}\text { Diário } \\
\text { Gaúcho }\end{array}$ & 2000 & 2010 - Diário da Foto \\
\hline $\begin{array}{l}\text { Correio do } \\
\text { Povo }\end{array}$ & 2009 (dentro do portal r7.com) & 2011 - FotoCorreio \\
\hline Aqui & - & - \\
\hline
\end{tabular}

*Data da primeira postagem.

FONTE - Elaborado pelas autoras

\section{Os blogs de fotografia como heterotopias}

Em nosso entendimento, a utilização do material fotojornalístico na web se deve não somente à ampliação dos espaços de publicação, mas, antes de tudo, ao advento da tecnologia digital de captação, veiculação e armazenamento dessas imagens. Munhoz (2007, p. 04) descreve três avanços tecnológicos que provocaram mudanças na rotina de produção e distribuição das fotografias jornalísticas: a digitalização do negativo (1995), a adoção massiva do uso de câmeras digitais pelos repórteres fotográficos das empresas jornalísticas (1998), e, por fim, a digitalização dos arquivos e criação de banco de imagens on-line das grandes agências de notícias do mundo como a AFP, Reuters, EFE, AP e Getty Image, abastecidas em tempo real e em qualquer parte do planeta. Soma-se a isso, a expansão da tecnologia de transmissão de dados (banda larga) como fator essencial para a inclusão massiva de imagens na rede.

Em novembro de 2012, eram cinco, dos 10 jornais de maior circulação no Brasil, que possuíam blogs de fotografia, segundo dados do Instituto Verificador de Circulação (IVC) ${ }^{37}$ : o Fotoglobo, do jornal carioca O Globo; o Olhar sobre o Mundo, do diário paulista O Estado de

37 Como em todo o recorte metodológico, o recurso ao IVC delimitou o universo a ser pesquisado, mas garantiu dados credíveis e de fácil acesso e consulta ao desenvolvimento da tese. Tais critérios possibilitaram a seleção de blogs fotojornalísticos produzidos por empresas de comunicação de grande porte reconhecidas nacionalmente, deixando de fora da pesquisa possíveis plataformas de jornais impressos com menor circulação. 
São Paulo; o FocoBlog, do periódico rio-grandense Zero Hora; o Diário da Foto, do Diário Gaúcho; e o Fotocorreio, do Correio do Povo, também do Rio Grande do Sul (Tabela 3).

TABELA 3

Jornais impressos de maior circulação diária do Brasil (2013) e seus blogs de fotografia ${ }^{38}$

\begin{tabular}{|c|c|c|c|c|}
\hline Jornal & $\begin{array}{c}\text { Estad } \\
0\end{array}$ & $\begin{array}{l}\text { Circulaç } \\
\text { ão* }\end{array}$ & $\begin{array}{c}\text { Blog de } \\
\text { fotografi } \\
a \\
\end{array}$ & Endereço web \\
\hline Super Notícia & MG & 302.472 & & \\
\hline Folha de SP & $\mathrm{SP}$ & 294.811 & & \\
\hline O Globo & RJ & 267.542 & FotoGlobo & $\begin{array}{l}\text { http://oglobo.globo.com/blogs/fo } \\
\text { toglobo/ }\end{array}$ \\
\hline Estadão & SP & 234.863 & \begin{tabular}{|l|} 
Olhar \\
sobre o \\
Mundo \\
\end{tabular} & $\begin{array}{l}\text { http://blogs.estadao.com.br/olha } \\
\text { r-sobre-o-mundo/ }\end{array}$ \\
\hline Extra & RJ & 225.622 & & \\
\hline Zero Hora & RS & 183.839 & FocoBlog & $\begin{array}{l}\text { http://wp.clicrbs.com.br/focoblo } \\
\text { g }\end{array}$ \\
\hline Daqui & GO & 162.013 & & \\
\hline Diário Gaúcho & RS & 159.485 & $\begin{array}{l}\text { Diário da } \\
\text { Foto }\end{array}$ & $\begin{array}{l}\text { http://wp.clicrbs.com.br/diarioda } \\
\text { foto }\end{array}$ \\
\hline Correio do Povo & RS & 140.189 & $\begin{array}{l}\text { FotoCorrei } \\
\text { o }\end{array}$ & $\begin{array}{l}\text { www.correiodopovo.com.br/blog } \\
\text { s/fotocorreio }\end{array}$ \\
\hline $\begin{array}{l}\text { Aqui (consolidado das } \\
\text { edições de MG, MA, } \\
\text { DF e PE) }\end{array}$ & MG & 129.455 & - & 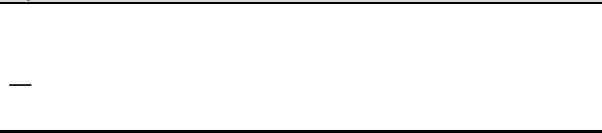 \\
\hline
\end{tabular}

*Dados referentes à circulação média diária dos jornais impressos pagos de jan. a dez. de 2013.

FONTE - Elaborado pelas autoras com dados do site da Associação Nacional de Jornais (2015).

O Fotoglobo, do jornal O Globo, do Rio de Janeiro, porém, anunciou sua "saída" da blogosfera no dia 30 de abril de 2013. Apesar de o endereço eletrônico manter-se ativo, o blog de fotografia Olhar sobre o Mundo, do jornal O Estado de São Paulo, também teve sua última publicação em 25 de janeiro de 2014. Em março de 2015, mais uma baixa: o blog Diário da foto, do jornal Diário Gaúcho deixou de ser atualizado. As razões para o encerramento das plataformas parecem girar em torno de exigências mercadológicas, ontológicas e tecnológicas. A primeira diz respeito à redução do quadro das empresas de comunicação, deslocando os fotógrafos para outras atividades afins (como filmar e editar vídeos). A segunda problematiza o próprio estatuto da imagem fotográfica, uma vez que a convergência entre suportes, produtores e receptores faça abolir fronteiras antes delimitadas. Já os avanços tecnológicos decretam o fim de plataformas que poderiam ser melhores exploradas, na medida em que

38 Foram excluídas do rol da pesquisa tumbrls ou galerias de foto por priorizarem a publicação de slideshows acompanhados de pequenas legendas. 
novos recursos surgem todos os dias e o desejo de superar uma possível defasagem leve a crer que a fórmula dos blogs pareça esgotada.

Dos dois únicos blogs que se mantiveram efetivamente ativos - FocoBlog (Zero Hora) e FotoCorreio (Correio do Povo) -, foram contabilizados 1.681 posts de outubro de 2009 a setembro de 2015. Numa primeira aproximação é possível perceber que, em geral, esses blogs possibilitam maior velocidade de produção e difusão de conteúdo. Neles, o material fotográfico não está totalmente atrelado aos critérios de noticiabilidade explorados pelos jornais diários e sua temporalidade não é fixa. No que se refere aos blogs que estamos analisando isto pode demonstrar a existência de "espaços de liberdade" para a criação fotojornalística, mesmo que, concomitantemente, muitas das fotografias publicadas nesses espaços sejam oriundas da cobertura realizada para os periódicos impressos. Na maior parte dos casos, os fotojornalistas ainda esperam o material sair no jornal para depois publicá-lo nos blogs, isto é, não "furam" o impresso. A postagem do FotoCorreio, publicada no dia 17 de abril de 2011 deixa evidente que uma das principais funções do blog seria o escoamento da produção fotográfica da empresa jornalística. Nela, o editor de fotografia do Correio do Povo, Ricardo Giusti, diz que,

O trabalho do fotojornalista é voltar para a redação com opções. (...) Entre todas possíveis escolhas, só aquela que melhor combinar com a notícia vai para as páginas do jornal. O resto, por melhor que seja, perde importância e é arquivado ou descartado. Às imagens não publicadas resta o esquecimento, ou o blog. Então, adiante com o blog! Porque nenhuma boa imagem merece ser esquecida.

Também, o trecho da postagem de Cynthia Vanzella publicada no Diário da Foto em 21 de julho de 2010 aponta nessa direção: "voltei para a redação com muitas fotos (...). No entanto, mais uma vez, o espaço do papel foi curto para tanto material, então resolvi mostrar aqui [no blog] alguns cliques exclusivos".

Em contrapartida, outros fotógrafos parecem aproveitar a elasticidade do espaço e do tempo do blog para mostrar diferentes aspectos do acontecimento noticiado ou explorar linguagens e temáticas que não são comumente publicadas nas páginas dos jornais impressos. Torna-se elucidativo dizer, neste sentido, que 36 postagens presentes nos blogs analisados congregam materiais extra-pauta e/ou de inspiração poética; o que estamos considerando uma via alternativa da produção fotojornalística. No dia 22 de novembro de 2013, por exemplo, o fotógrafo Bruno Alencastro publicou no Focoblog um "ensaio sem compromisso da sacada de um hotel em São Paulo" realizado enquanto esperava pela pauta (Figura 1). As imagens que acompanham o texto revelam um olhar atento às formas e a composição plástica, marcando bem a abordagem não-informativa da série. Dificilmente, tais fotografias seriam publicadas no jornal impresso, não somente por se afastarem do tema da pauta, mas, sobretudo, pela ausência ou pouca participação de elementos humanos em ação nas cenas. 


\section{FIGURA 1 - ENSAIO "EXTRA-PAUTA" DE BRUNO ALENCASTRO}
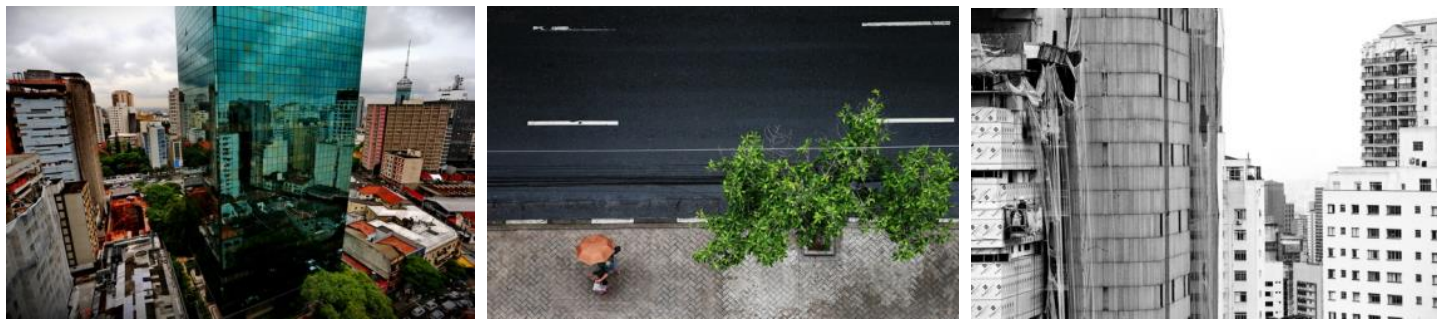

Fonte: FocoBlog - http://wp.clicrbs.com.br/focoblog/2013/11/22/?topo=13,1,1,,13

Mesmo caso pode ser observado nas imagens realizadas pelo fotojornalista Cristiano Estrela, que na época integrava o quadro de repórteres do Correio do Povo. Esperando pela pauta, ele aproveitou a elasticidade do espaço e do tempo proporcionada pela plataforma para explorar linguagens e mostrar outros aspectos do acontecimento (Figura 2). No dia 27 de maio de 2011, portanto, "enquanto aguardava pelo início de um evento no hospital psiquiátrico São Pedro, em Porto Alegre, o fotógrafo aproveitou para fazer imagens do local. O evento foi adiado, mas a espera do colega nos rendeu belas fotos!" (Trecho da Postagem Fotocorreio).

FIGURA 2 - POST "A ESPERA DA PAUTA"
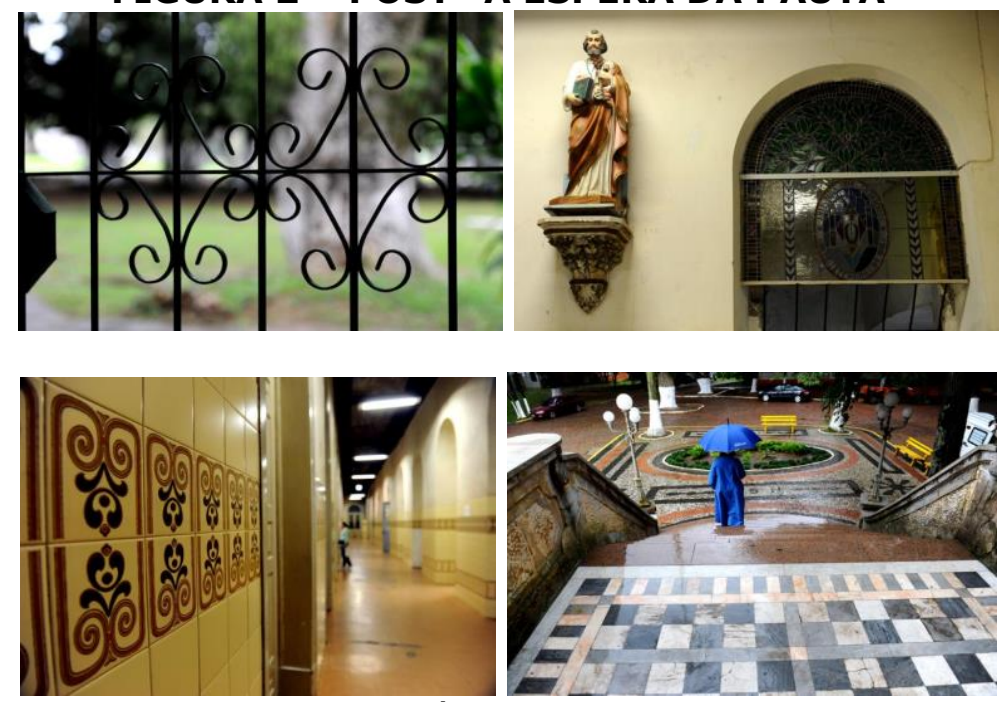

Fonte: FotoCorreio - (Crédito das fotos: Cristiano Estrela) http://www.correiodopovo.com.br/blogs/fotocorreio/?p=24

Tal recurso também está presente no blog Olhar sobre o Mundo, onde o fotógrafo Hélvio Romero direciona suas lentes para o "céu de outono" (Figura 3). O texto que acompanha o ensaio fotográfico é bem sugestivo quanto ao caráter plástico e atemporal das imagens: "é como se Romero cruzasse sua percepção estética apurada com sua experiência de repórter fotográfico, de profissional de jornal diário. São fotos que vão sobreviver à edição de amanhã e a temporada de outono" (Trecho de Postagem Olhar sobre o Mundo, 20/03/2012). 

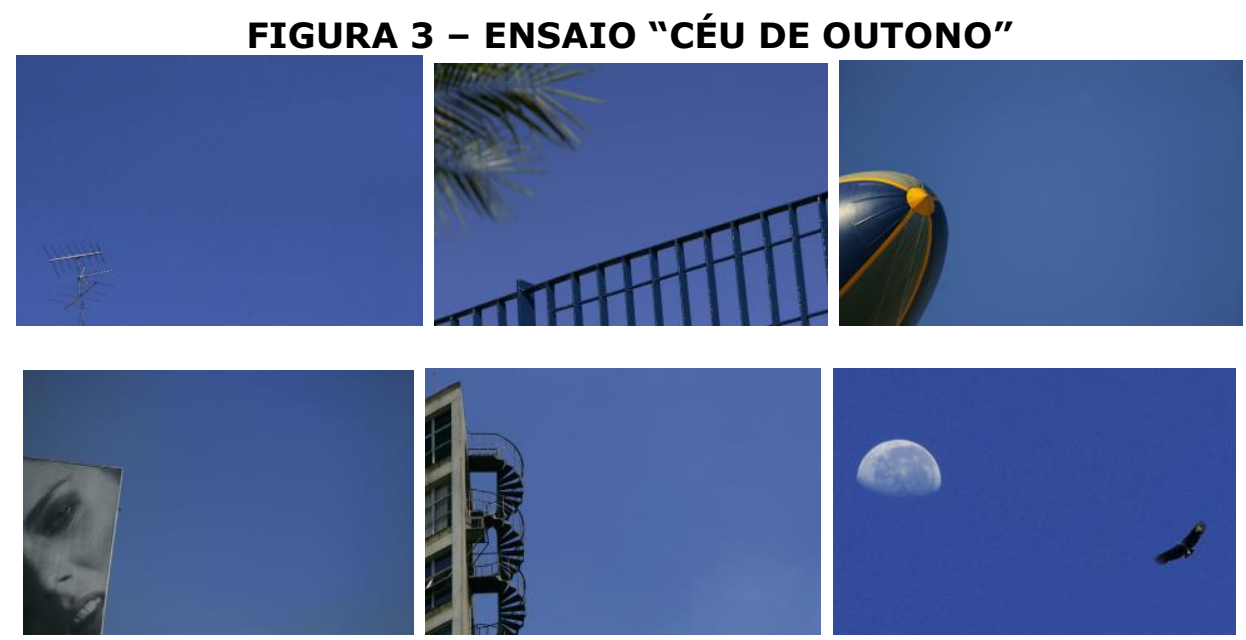

Fonte: Olhar sobre o Mundo - (Crédito das fotos: Hélvio Romero) http://blogs.estadao.com.br/olhar-sobre-o-mundo/ceu-de-outono/

O recurso estético se apresenta novamente no ensaio assinado pelo atual editor de fotografia de Zero Hora, Jefferson Botega. No dia 30 de junho de 2010, o fotógrafo escalado para cobrir os preparativos da Estação de Inverno, evento realizado no município de Gramado (RS), aproveitou para fazer algumas imagens para o Focoblog sobre os "detalhes da cidade que, muitas vezes, passam despercebidos" (Figura 4).

FIGURA 4 - ENSAIO "DETALHES DE GRAMADO"
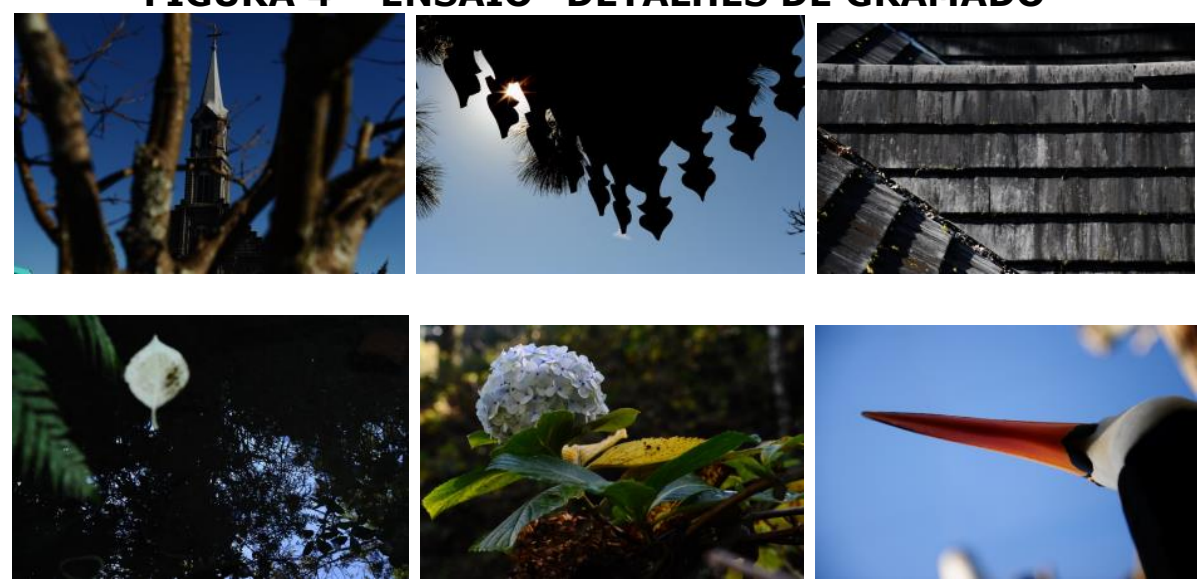

Fonte: FocoBlog - (Crédito das fotos: Jefferson Botega)

http://wp.clicrbs.com.br/focoblog/2010/06/30/detalhes-de-gramado/?topo $=13,1,1,, 13$

Já o repórter fotográfico Marcelo Oliveira realizou uma imagem (Figura 6) que fez a colega Cynthia Vazella escrever: "era apenas uma pauta rotineira, mas ele olhou de novo e viu, do lado de fora do acontecimento, a mistura de cores, sombras e texturas" (Trecho de Postagem Diário da Foto, 17/09/2010). 


\section{FIGURA 6 - POST "OLHA DE NOVO"}

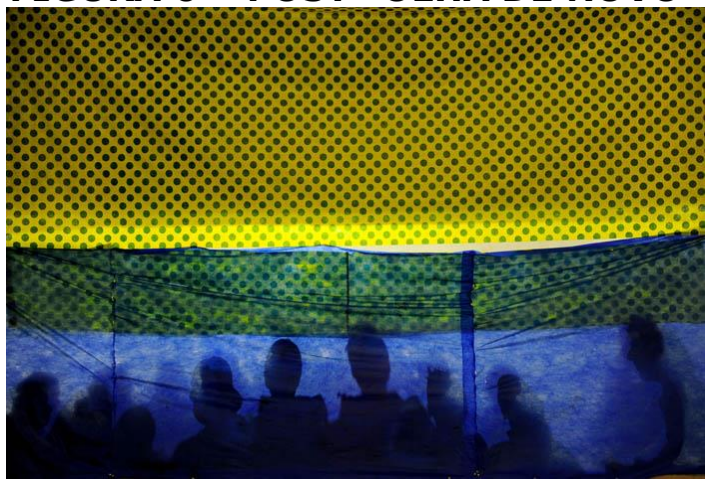

Fonte: Diário da Foto - (Crédito das fotos: Marcelo Oliveira)

http://wp.clicrbs.com.br/diariodafoto/2010/09/17/olha-de-novo/?topo=52,1,1,186,e186

Vale destacar, ainda, a realização de materiais exclusivos para a plataforma blog, como o caso da cobertura do $5^{\circ}$ PoaTatooFest, encontro de tatuadores ocorrido em Porto Alegre (RS) no dia 26 de abril de 2011, realizada pelos fotógrafos do Correio do Povo (Figura 7).

\section{FIGURA 7 - ENSAIO "ARTE NA PELE"}
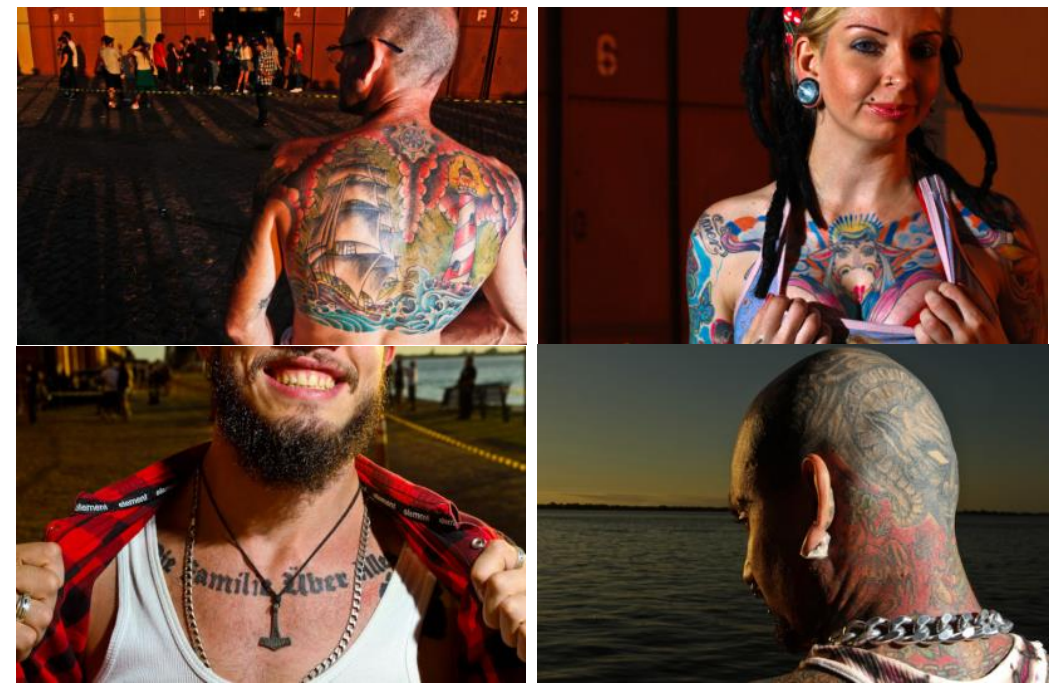

Fonte: FotoCorreio - (Crédito das fotos: Bruno Alencastro, Pedro Revillion, Vinícius Roratto) http://www.correiodopovo.com.br/blogs/fotocorreio/?p=12

Tais ensaios passam a operar numa "linha de fuga"39 dentro do fotojornalismo, pois contemplam o que podemos chamar de poética visual ${ }^{40}$. Não existe um conceito fechado sobre poesia visual, mas sua função seria basicamente abolir as diferenças entre os gêneros artísticos, onde os elementos visuais assumiriam o protagonismo da obra. Ao comportarem narrativas poéticas, portanto, o espaço dos blogs funcionariam, aos olhos dos os

39 Deleuze e Guattari (1995) irão trabalhar na obra Mil Platôs o conceito de "Rizoma" tomando-o emprestado da botânica. Rizoma é uma raiz que possui crescimento polimorfo e horizontal, não apresentando uma direção clara e definida. As linhas de fuga, por sua vez, são aquelas que escapam da tentativa totalizadora e fazem contato com outras raízes, seguem outras direções. "Não existem pontos ou posições num rizoma como se encontra numa estrutura, numa árvore, numa raiz. Existem somente linhas" (DELEUZE \& GUATTARI, Mil Platôs I, 1995).

40 Sobre isso ver Muñoz (2014). 
fotojornalistas que compõem o quadro das redações, como espécies de "utopias" possíveis, na acepção foucaultiana do termo, ou seja, um "espaço maravilhoso e liso" (FOUCAULT, 1987, p. 07), capaz de agregar liberdades criativas e temporalidades estendidas. Ou seja, espaços que se diferenciam dos demais por não estarem subordinados aos discursos hegemônicos (no caso do fotojornalismo, aos princípios de objetividade e realismo), embora não rompam totalmente com eles. "Como sucede en todo espacio heterotopico, el principio de realidad cede paso al principio de la imaginación" (CATALÁ, 2012, p. 59-63).

Podemos pensar, então, nesses blogs como heterotopias, uma vez que se tornaram espaços cujos repórteres fotográficos refletem sobre a cobertura imagética originalmente pensada para as páginas dos periódicos, desviando tais imagens do seu destino original, reelaborando seus sentidos e descrevendo suas práticas, mesmo que, mantenham-se pautados e sigam as dinâmicas internas do jornal em que trabalham.

Para Foucault (1998; 2005), conforme sublinhado anteriormente, há seis princípios que regem as heterotopias, todos aplicáveis à análise dos blogs de fotografia dos jornais brasileiros. O primeiro é o de que "não há nenhuma cultura no mundo que deixe de criar as suas heterotopias" e o segundo é que elas "assumem variadíssimas formas". O terceiro princípio diz que "uma sociedade, à medida que a sua história se desenvolve, pode atribuir a uma heterotopia existente uma função diversa da original". Traçando um paralelo, os blogs inicialmente foram utilizados como diários virtuais e criados para a produção individual e autoral; porém, ganharam outras funções ao longo do tempo como, por exemplo, ferramenta de comunicação organizacional de uso profissional e coletivo. Além disso, ao mesmo tempo em que movimentam saberes específicos, tais plataformas são vistas como espaços institucionais e tidas como produtos pelas empresas das quais fazem parte. Neste sentido, tais plataformas se transmutaram, ao longo dos anos, em bens que respondem não só as necessidades de um grupo social, mas principalmente às necessidades do mercado, cujo ciclo de vida depende também de estratégias que garantam a audiência e mobilize tanto consumidores quanto concorrentes.

O quarto princípio foucaultiano de heterotopia sublinha que esses lugares conseguem "sobrepor, num só espaço real, vários espaços, vários sítios que por si só seriam incompatíveis". No que se refere aos blogs, as possibilidades de fazer links e de realizar conexões inimagináveis fora do espaço virtual, o define como "ponto de encontro" de outros espaços (PRIMO, 2008, p. 123). O próprio termo original weblog significa "arquivo web".

Já o quinto princípio descreve a relação das heterotopias com "pequenos momentos, pequenas parcelas do tempo", aquilo que Foucault $(1998 ; 2005)$ chamou de heterocronias. Ou seja, uma heterotopia se caracteriza também por engendrar "uma certa ruptura do homem com a sua tradição temporal" e tende a acumular esses diferentes tempos em um só espaço. Se nos detivermos no quinto princípio, também podemos chegar a algumas conclusões. Os blogs são espaços onde o conteúdo é organizado em ordem cronológica reversa, isto é, o 
último post é aquele que primeiro aparece na página, privilegiando o caráter atual desse conteúdo. Neste sentido, é preciso que seu ciclo de vida seja breve, que "desapareça" em meio a outros conteúdos para bem marcar seu lugar no tempo. Concomitantemente, esse "desaparecimento" deve fazer eco, ressonar, lançar-se no futuro. Deve, ao fim e ao cabo, operar num continnum. Na medida em que os conteúdos vão sendo atualizados nesses espaços, gera-se um arquivo cujas inúmeras e diferentes temporalidades se acumulam e se sobrepõem. Além disso, há o abandono das plataformas na blogosfera, cujos endereços permanecem ativos e nos remetem ao dia em que as empresas jornalísticas decidiram, deliberadamente, deixá-los à míngua. Esses espaços tornam-se literalmente não-lugares; ruínas de sítios heterotópicos, ou nas palavras de Catalá (2012, p. 60), "lo que queda es un no lugar en el que resuenan los ecos fantasmáticos del lugar que fue".

O sexto e o último princípio estabelecido por Foucault (1998) descreve as heterotopias como "um sistema de abertura e encerramento que as torna tanto herméticas como penetráveis". Se pensarmos nos blogs de uma forma geral, percebemos que suas estruturas se assemelham e que somente quem possui acesso ao gerenciador é autorizado a inserir conteúdo. Sendo assim, os espaços de interação com o público "externo" se dão, na grande maioria, por meio dos comentários, mostrando que nem mesmo as interfaces são neutras. Mas Foucault (1998) vai além,

Ainda que à primeira vista pareçam ser aberturas, servem de forma velada a curiosas exclusões. Todos podem entrar nestes sítios heterotópicos, mas essa é apenas uma ilusão: pensamos que entramos ali onde somos, simplesmente pelo fato de ali termos entrado, excluídos.

A estratégia fica evidente, principalmente, quando se trata de "ensinar" as práticas fotográficas e analisar as questões técnicas das imagens enviada pelos leitores. Blogs como o extinto FotoGlobo, do jornal carioca $O$ Globo, enfatizavam a relação de oposição entre profissionais (os editores do blog) e os amadores (os internautas) e deixavam seus limites de atuação bem claros. O blog citado era o único dos que compõe o nosso corpus que vinha com a proposta de publicar o material dos leitores de forma constante, sendo eles fotógrafos profissionais ou não, e fazendo uma avaliação crítica da composição da fotografia enviada.

Como recebiam inúmeros e-mails dos internautas solicitando a publicação de suas fotografias, os idealizadores do FotoGlobo criaram um "manual de sobrevivência do blog", cujo texto revelava o espaço delimitado ao público usuário e o intuito pedagógico dos profissionais frente aos diletantes. O manual deveria servir para os internautas entenderem "como o blog funciona e melhorar a sua participação". Além disso, especificava o tamanho das imagens a serem enviadas - "450 pixels no lado maior, isto é, se a foto for horizontal, serão 450 pixels na largura, se vertical, 450 pixels na altura" e, em outros trechos, detalhava a dinâmica de funcionamento da plataforma: 
Às segundas-feiras Marcelo Carnaval [repórter fotográfico do O Globo e editor do blog] publica as fotos mais criticadas da semana, e tem como ponto principal a escolha do vencedor do Troféu Pede para sair, pela pior foto. (...) Quarta é o dia das aulas práticas, onde o Carnaval mostra como melhorar as suas fotos e na sexta-feira, como bom carioca, o blog é só festa, com as melhores da semana.

Para encerrar, o manual explicitava que os comentários eram os espaços de participação dos internautas por excelência: "para os participantes do blog os comentários são a melhor forma de retorno do seu trabalho, por isso não esqueça a gentileza, principalmente na hora de criticar". Antes de se configurarem como um elo entre os fotojornalistas e os leitores/colaboradores do blog, fazendo emergir novos "contratos de leitura"41 e humanizando a empresa diante de seus públicos, tais enunciados engendram operações que instituem regras para a participação do público "externo", numa clara estratégia de defesa do campo e controle sobre o fluxo das informações. Afinal, é por intermédio dos próprios fotógrafos do $O$ Globo que os amadores ganhavam notoriedade e seu material, visibilidade. Enfim, era justamente pelo fato dos profissionais se destacarem como os guardiões do saber fotojornalístico que se atribuía relevância ao papel social desempenhado pelos mesmos.

\section{Conclusões instáveis}

A partir do conjunto de postagens reunidos no presente texto, portanto, estamos entendendo os blogs de fotografia como utopias possíveis ou, conforme Foucault, como heterotopias: ainda que, muitas vezes, o conteúdo postado fique aquém das expectativas dos profissionais e das potencialidades das ferramentas, os fotojornalistas têm praticado nos blogs algumas experiências criativas com maior liberdade, autoria ${ }^{42}$, imersão documental e transposição das barreiras entre arte e informação. Para Luna (in CATALÁ, 2014, p. 208), as heterotopias, justamente, "se construyen sobre espacios-otros que fluctúan entre el documental y la ficción".

Concomitantemente, é possível perceber que os fotógrafos responsáveis pelos blogs vivem um dilema: ou dão vazão às potencialidades artísticas em ensaios pensados exclusivamente para tais plataformas ou as utilizam para escoar a produção imagética que os jornais impressos desprezaram; ou reforçam seu papel social em discursos que apontam para a defesa do campo profissional ou tiram proveito das linguagens que tornam porosas as fronteiras entre fotógrafos de imprensa e artistas. Neste sentido, "la heterotopia, se convierte en una zona (...) que no es tanto de libertad como de incertidumbre" (CATALÁ DOMÉNECH,

41 Umberto Eco (1987) falou sobre "leitor modelo", cujas características, idealizadas por quem produzia o conteúdo, estabeleciam um padrão de interlocução e uma espécie de "contrato" entre emissor e receptor. Eliseo Verón (2004, p. 216), por sua vez, problematiza o conceito de Eco ao dizer que: "o conceito de contrato de leitura implica que o discurso de um suporte de imprensa seja um espaço imaginário onde percursos múltiplos são propostos ao leitor; em uma paisagem (...) na qual o leitor pode escolher seu caminho com mais ou menos liberdade".

42 Aqui estamos usando o termo autoria para designar o que Adghirni e Pereira (2006, p. 14) estão chamando de "jornalismo de autor", onde o "blogueiro assume uma posição de líder, de difusor de ideias, de formador de opinião que ele havia perdido como indivíduo no processo de industrialização da informação". 
2012, p. 59). O que deve ser repensado, portanto, não é somente o que tais plataformas têm a oferecer, mas o que as empresas jornalísticas, - e em especial os repórteres fotográficos -, estão solicitando delas. Finalmente, se o trabalho fotojornalístico dentro do espaço das redações é regido por Chronos; obedecendo à deadlines e sendo submetidos à ordem cronológica dos dias, os blogs de fotografia parecem reivindicar outros arranjos temporais que circunscrevam as práticas e as produções fotojornalísticas a espaços fluídos, dinâmicos e abertos a experimentações.

\section{Referências}

ADGHIRNI, Zélia Leal; PEREIRA, Fábio Henrique. Perfil Profissional no Ciberjornalismo: o blog como espaço de autoria e identidade na web. Brasília: Associação Brasileira de Pesquisadores em Jornalismo (SBPJor), 2006, p. 01-16.

ASSOCIAÇÃO NACIONAL DE JORNAIS. Os Maiores Jornais do Brasil de Circulação Paga, por Ano. Disponível em: < http://www.anj.org.br/a-industria-jornalistica/jornais-nobrasil/maiores-jornaisdo- brasil/>. Acesso em: 13 fevereiro 2015.

AUGÉ, Marc. Não-Lugares: introdução a uma antropologia da supermodernidade. Campinas: Papirus, 1994.

BAUMAN, Zygmunt. Vida Líquida. Rio de Janeiro: Zahar, 2007.

CASTELLS, Manuel. A Sociedade em Rede: Vol. 1. 2. ed. São Paulo: Paz e Terra, 1999.

CASTRO. Edgardo. Introducción a Foucault. Buenos Aires: Siglo Veintiuno, 2014.

CERTEAU, Michel de. A invenção do cotidiano: artes de fazer. 19 ed. Petrópolis: Vozes, 2012.

DELEUZE, G; GUATTARI, F. Mil Platôs: capitalismo e esquizofrenia. Vol.1. Rio de Janeiro: Ed. 34, 1995.

DIÁRIO DA FOTO. Disponível em: <http://wp.clicrbs.com.br/diariodafoto>. Acesso em: 24 novembro 2015.

DOMÉNECH, Josep M. Català. El murmullo de las imágenes: imaginación, documental y silencio. Santander: Shangrila, 2012.

ECO, Umberto. Lector in Fabula. São Paulo: Perspectiva, 1987.

ESCOBAR, Juliana Lopes. Blogs como nova categoria de webjornalismo. IN: AMARAL, Adriana. MONTARDO, Sandra. RECUERO, Raquel (orgs.). Blogs.com: Estudos sobre blogs e comunicação. São Paulo: Momento editorial, 2009, p. 217-235.

FOCOBLOG. Disponível em: <http://wp.clicrbs.com.br/focoblog>. Acesso em: 24 novembro 2015.

FOLETTO, Leonardo. Blogosfera x Campo Jornalístico: aproximação e consequências. In: AMARAL, Adriana; RECUERO, Raquel; MONTARDO, Sandra (Orgs.). Blogs.Com: estudos sobre blogs e comunicação. São Paulo: Momento Editorial, 2009a, p. 199-278.

FOLETTO, Leonardo. Blog Jornalístico: definição e características na blogosfera brasileira. Florianópolis: Universidade Federal de Santa Catarina, 2009, 192 f. Dissertação (Mestrado em 
Jornalismo). Centro de Comunicação e Expressão do Programa de Pós-Graduação em Jornalismo da Universidade Federal de Santa Catarina, Florianópolis, 2009b.

FOTOCORREIO. Disponível em: http://www.correiodopovo.com.br/blogs/fotocorreio/>. Acesso em: 24 novembro 2015.

FOTOGLOBO. Disponível em: <http://oglobo.globo.com/blogs/fotoglobo/>. Acesso em: 12 junho 2013.

FOUCAULT, Michel. De Outros Espaços. 1998. Disponível em:

<http://www.virose.pt/vector/periferia/foucault_pt.html>. Acesso em: 24 nov. 2015.

Espaços Outros. In: MIRANDA, José A. Bragança de; COELHO, Eduardo Prado (Orgs.). Revista de Comunicação e Linguagens. Universidade Nova de Lisboa. Lisboa: Relógio D'Água Editores. Junho de 2005, p. 109-141.

As Palavras e as Coisas: uma arqueologia das ciências humanas. 4. ed. São Paulo: Martins Fontes, 1987.

GIDDENS, Anthony. A Constituição da Sociedade. 2. ed. São Paulo: Martins Fontes, 2003.

HARVEY, D. Spaces of Hope. Los Angeles: University of California Press, 2000.

INSTITUTO VERIFICADOR DE CIRCULAÇÃO. Disponível em: <http://www.ivcbrasil.org.br/>. Acesso em: 01 janeiro 2015.

JOHNSON, P. Interpretations of Heterotopia. 2012. Disponível em: <http://www.heterotopiastudies.com>. Acesso em: 24 nov. 2015.

LEFEBVRE, Henri. A produção do espaço. 2006. Disponível em: <www.mom.arq.ufmg.br/mom/arq.../1a.../A_producao_do_espaco.pdf>. Acesso em: 24 nov. 2015.

LUNA, Maria. El lugar de la heterotopía en la mirada documental. In: CATALÁ, Josep M. (Ed.). El cine de pensamiento: formas de la imaginación tecno-estética. Castelló de la Plana: Publicacions de la Universitat Jaume I; Barcelona: Universitat Autònoma de Barcelona: Universitat Pompeu Fabra; València: Universitat de València; Aldeia Global, 2014, p. 205-223.

MUNHOZ, Paulo; PALACIOS, Marcos. Fotografia, Blogs e Jornalismo na Internet: oposições, associações e simbioses. Grupo de Pesquisa em Jornalismo On-line, Faculdade de Comunicação, Universidade Federal da Bahia, 2007, p. 01-22. Disponível em:

<http://www.almanaquedacomunicacao.com.br/wp-content/uploads/2011/10/Fotografia-

Blogs-e- Jornalismo-na-Internet.pdf>. Acesso em: 08 de novembro de 2012.

MUÑOZ, Llorenç Raich. Poética Fotográfica. Madrid: Casimiro, 2014.

OLIVEIRA, Ariel Lara de. $\mathbf{O}$ jornalismo em quadrinhos na internet: as reportagens gráficosequenciais do site Cartoon Movement. Porto Alegre: Universidade Federal do Rio Grande do Sul - UFRGS, 2015, 164 f. Dissertação (Mestrado em Comunicação). Programa de PósGraduação em Comunicação e Informação, Porto Alegre, 2015.

PALACIOS, Marcos; MUNHOZ, Paulo. Fotografia, Blogs e Jornalismo na Internet: Oposições, apropriações e simbioses. In: BARBOSA, Suzana. Jornalismo Digital de Terceira Geração. Covilhã: Universidade da Beira Interior, 2007, p. 63-84.

PALACIOS, Marcos; MIELNICZUK, Luciana; BARBOSA, Suzana; RIBAS, Beatriz; NARITA, Sandra. Um mapeamento de características e tendências no jornalismo online 
brasileiro. Grupo de Pesquisa em Jornalismo On-line, Faculdade de Comunicação, Universidade Federal da Bahia, 2002, p. 01-15. Disponível em: <http://www.facom.ufba.br/jol/pdf/2002_palacios_mapeamentojol.pdf>. Acesso em: 03 de novembro de 2012.

PRIMO, Alex. Os blogs não são diários pessoais online: matriz para a tipificação da blogosfera. Revista FAMECOS - Comunicação e Relações Sociais, Porto Alegre (RS), Pontifícia Universidade Católica do Rio Grande do Sul, n. 36, p. 122-128, ago. 2008.

RAMONET, Ignacio. A Tirania da Comunicação. Petrópolis: Vozes, 1999.

RELPH, E. Post-modern geography. In: The Canadian Geographer, v.35, n¹, 1991. pp. 98105.

SOJA, E. Heterotopologies: a remembrance of other spaces in the citadel of L.A. In: WATSON, S. e GIBSON, K. (Ed.). Postmodern cities and spaces. Oxford: Blackwell, 1995.

SOJA, Edward. Geografias Pós-Modernas. Rio de Janeiro: Jorge Zahar, 1993.

VERÓN, Eliseo. Fragmentos de um tecido. São Leopoldo: UNISINOS, 2004. 